\title{
Distribution and geological sources of selenium in environmental materials in Taoyuan County, Hunan Province, China
}

\author{
Runxiang Ni $\cdot$ Kunli Luo $\cdot$ Xinglei Tian • \\ Songgui Yan · Jitai Zhong $\cdot$ Maoqiu Liu
}

Received: 4 February 2015/Accepted: 14 October 2015/Published online: 12 November 2015

(C) Springer Science+Business Media Dordrecht 2015

\begin{abstract}
The selenium (Se) distribution and geological sources in Taoyuan County, China, were determined by using hydride generation atomic fluorescence spectrometry on rock, soil, and food crop samples collected from various geological regions within the county. The results show Se contents of 0.02-223.85, 0.18-7.05, and $0.006-5.374 \mathrm{mg} / \mathrm{kg}$ in the rock, soil, and food crops in Taoyuan County, respectively. The region showing the highest Se content is western Taoyuan County amid the Lower Cambrian and Ediacaran black rock series outcrop, which has banding distributed west to east. A relatively high-Se environment is found in the central and southern areas of Taoyuan County, where Quaternary Limnetic sedimentary facies and Neoproterozoic metamorphic volcanic rocks outcrop, respectively. A
\end{abstract}

R. Ni $\cdot$ K. Luo $(\bowtie) \cdot$ X. Tian

Institute of Geographic Sciences and Natural Resources

Research, Chinese Academy of Sciences, Beijing 100101,

China

e-mail: kunliluo@sohu.com

R. Ni · X. Tian

University of Chinese Academy of Sciences,

Beijing 100049, China

\section{S. Yan $\cdot$ J. Zhong}

Taoyuan Institute of Selenium Enriched Production

Research, Hunan 415700, China

M. Liu

Agricultural Bureau of Taoyuan County, Hunan 415700, China relatively low-Se environment includes the central and northern areas of Taoyuan County, where Middle and Upper Cambrian and Ordovician carbonate rocks and Cretaceous sandstones and conglomerates outcrop. These results indicate that Se distribution in Taoyuan County varies markedly and is controlled by the Se content of the bedrock. The Se-enriched Lower Cambrian and Ediacaran black rock series is the primary source of the seleniferous environment observed in Taoyuan County. Potential seleniferous environments are likely to be found near outcrops of the Lower Cambrian and Ediacaran black rock series in southern China.

Keywords Selenium distribution $\cdot$ Selenium geological sources $\cdot$ Taoyuan County

\section{Introduction}

Selenium (Se) is an essential element for both animals and humans; both its deficiency and excess can lead to Se-related diseases (Fordyce 2013). For example, Keshan disease and Kaschin-Beck disease (KBD) are both related to an environmental Se deficiency (Tan et al. 2002); human and animal selenosis has been reported from Enshi County, China, as a result of high level of Se in the environment (Fordyce et al. 2000). Combs (2001) has summarized that food system need to provide at leat $40 \mu \mathrm{g}$ Se/day (per adult), and a provisionally upper tolerable nutrient intake level for 
Se was set at $400 \mu \mathrm{g} /$ day for adults (FAO and WHO 2001). Therefore, the content and distribution of Se in environmental materials such as soil and food crops has received significant attention (Fordyce 2013; Duntas and Benvenga 2014; Johnson et al. 2000; Wang et al. 2013). Moreover, geochemical surveys of soil Se have been conducted worldwide (CCME 2009; Tan et al. 2002; US Geological Survey 2008; Yamada et al. 2009; Rawlins et al. 2012).

With regard to the distribution of soil Se, values in the USA range from 0.1 to $5.32 \mathrm{mg} / \mathrm{kg}$ (US Geological Survey 2008), with the highest concentrations found in the soils of the Great Plains and the most deficient soils found in the Pacific Northwest, northeastern USA, and the Southeastern Seaboard states (Kubota et al. 1967). In England and Wales, soil Se values range from 0 to $7 \mathrm{mg} / \mathrm{kg}$ (Rawlins et al. 2012). In Japan, the Se content of agricultural soils ranges from 0.05 to $2.80 \mathrm{mg} / \mathrm{kg}$, with soils in the Kanto, Tohoku, Hokkaido, and Kyushu regions having the highest concentrations (Yamada et al. 2009). Thus, the Se content in soils varies markedly, and its distribution is extremely uneven.

With regard to the sources of Se in soils, particularly in the USA, seleniferous soils are related to Seenriched Permian shales and Cretaceous rocks (Moxon 1937). In England and Wales, seleniferous soils are associated with organic matter and Lower Liassic (Jurassic) black shales (Rawlins et al. 2012). In Japan, seleniferous soils are related to organic-rich sediments and volcanic materials (Yamada et al. 2009).

With regard to plants, Se concentrations are generally relatively low at less than $0.1 \mathrm{mg} / \mathrm{kg}$ (Plant et al. 2014), although certain plants such as Cardamine hupingshanesis can accumulate high Se concentrations of up to $8000 \mathrm{mg} / \mathrm{kg}$ (Yuan et al. 2013). The Se content in plants is influenced by the Se content and speciation in the soil and the species of the plant. However, several factors require further study: the effects of the rock type and rock Se content on the content and distribution of Se in soil; the reason for the variance in Se content in identical plant species depending on the different geological stratum in their growth area is unknown.

Several studies have investigated the Se content and distribution patterns in soils, feed, and food for human consumption in China. For example, Liu et al. (1985) discussed the Se contents and distribution in forage feed. Samples were collected to represent a variety of terrains, soil types, and agricultural zones. In total, they analyzed 11,467 samples from 1782 sampling sites across 1103 counties, including one to two sampling sites per county. The results showed that the Se contents in the forage feed of 790 counties, $\sim 71.6 \%$ of those investigated, were $<0.05 \mathrm{mg} / \mathrm{kg}$, suggesting that most forage feed in China is Se deficient.

The Endemic Disease Research Group at the Institute of Geographic Sciences and Natural Resources Research (IGSNRR) created a "Selenium Ecological Landscape Map of China" based on 2000 soil samples (personal communication with Mr. Tan, the author of "Selenium Ecological Landscape Map of China") in which a grading system for soil Se content was proposed. In this scale, $\geq 3.0 \mathrm{mg} / \mathrm{kg}$ is excessive; $0.40-3.0 \mathrm{mg} / \mathrm{kg}$ is high; $0.175-0.40 \mathrm{mg} / \mathrm{kg}$ is moderate; $0.125-0.175 \mathrm{mg} / \mathrm{kg}$ is marginal; and $<0.125 \mathrm{mg} /$ $\mathrm{kg}$ is deficient (Tan 1989). This map, which shows the macroscopic distribution pattern of Se in Chinese soils, contains fundamental data important for all subsequent research in this area. However, certain limitations remain.

China covers a vast geographical area; most of its counties are large with relatively complex geology. Furthermore, the Se contents of soils and plants vary greatly across Chinese counties. For example, soils with high Se concentrations (16-36 mg/kg) in the two areas with the most cases of selenosis (Ziyang County, Shaanxi, and Enshi County, Hubei Province) are locally distributed (Luo et al. 2004; Fordyce et al. 2000). These two selenosis areas are small, at about 0.5 and $0.42 \mathrm{~km}^{2}$, respectively. The Se concentrations in the soils adjacent to these selenosis areas are significantly lower, at $0.034-0.288 \mathrm{mg} / \mathrm{kg}$ (Fordyce et al. 2000). Therefore, data from just one or two sampling sites per county are not necessarily representative of the actual $\mathrm{Se}$ contents and distribution patterns. Increasing the number of samples is necessary in general; gaining an in-depth understanding of the distribution and geological sources of $\mathrm{Se}$ in specific areas requires detailed investigation.

In addition, because the endemic disease research group at IGSNRR focused on Se deficiency, data were collected in areas of relatively low Se content, including areas with high rates of Keshan disease and KBD. Probable areas of high Se were outside of the group's consideration. 
Moreover, the average Se content of soil from a specific area was generally calculated as an arithmetic value based on the available samples from that area. However, the relative proportion of areas with different Se contents was not considered. Further, China has 2853 counties, many of which still require Se investigations. Therefore, the distribution and sources of Se in a specific area, such as a county, still require detailed investigation.

In summary, Se distribution in the environment is extremely uneven, and soil origin material such as bedrock, volcanic materials, and soil components such as organic matter and oxides affect Se distribution in soil and plants. Further survey is needed because the details of existing investigations are insufficient for reflecting Se levels in a relatively small area such as a county.

Taoyuan County has the largest cultivated land area in Hunan Province and is one of China's important agricultural bases for rice and its by-products. For many years, Se levels in Taoyuan County have been considered deficient. In response, the "selenium supplement program" was instigated in December 2006. The purpose of this program was to improve human dietary Se intake by developing, producing, and consuming Se-enriched agricultural and sideline products. However, some studies have found that not all areas have a Se deficiency; some Taoyuan County soils have relatively high Se concentrations (Ge et al. 1996). Thus, Se content and distribution patterns for the entire county are poorly understood.

The objectives of the present study are to investigate the concentrations and distribution patterns of $\mathrm{Se}$ in environmental materials such as bedrock, soil, and food crops in Taoyuan County and to discuss the geological sources of Se in soils and food crops in this county.

\section{Geological and geographical setting}

Taoyuan County is located in the northwest region of Hunan Province, China (longitude: $110^{\circ} 50^{\prime} 36^{\prime \prime} \mathrm{E}-$ $110^{\circ} 36^{\prime} 32^{\prime \prime} \mathrm{E}$; latitude: $28^{\circ} 24^{\prime} 30^{\prime \prime} \mathrm{N}-29^{\circ} 24^{\prime} 13^{\prime \prime} \mathrm{N}$ ). Taoyuan is bordered by Shimen Country to the north; Anhua to the south; Yuanling, Cili, and Yongding to the west; and Linli and Dingcheng to the east (Fig. 1).

Geologically, Taoyuan is located in the northeast region of the Xuefeng and Wuling uplifts and southwest of the western Dongting depression. The earliest stratigraphic unit in Taoyuan is the Neoproterozoic Lengjiaxi Group. Stratigraphic development of the Upper Proterozoic and Lower Paleozoic deposits is complete, with the exceptions of missing upper Silurian strata; most of the Upper Paleozoic strata are also missing. The stratigraphic distribution within Taoyuan Country is well defined with the Neoproterozoic Lengjiaxi Group slates outcropping mainly in the south, Neoproterozoic Banxi Group slates and sandstones present in the south and west, Neoproterozoic Ediacaran black siliceous rocks and Cambrian black shales and limestones present in the west, Ordovician limestones present in the northeast and northwest, Silurian siltstones present in the north, and Cretaceous sandstones and mudstones present in the central region. Paleogene mudstones and Quaternary limnetic sedimentary facies outcrop along the Yuanjiang River (Fig. 1).

\section{Materials and methods}

A total of 385 samples were collected from various geological regions of the county. The rock samples were collected from outcrops with fresh, unaltered faces. Following collection, all samples were washed with tap water and then with deionized water before being dried in a laboratory at room temperature. The soil samples were collected from cultivated farmland and were dried in a laboratory at room temperature. Branches, leaves, grass roots, and stones found within soil samples were removed with plastic tweezers. The dried rocks and soil samples were crushed until they were able to pass through a 100-mesh sieve and were stored in sealed plastic bags. Food crop samples were collected from the areas in which the soil samples were collected, washed with tap water followed by deionized water, and dried at $60{ }^{\circ} \mathrm{C}$. The dried crop samples were also crushed to 100 mesh and were stored in sealed plastic bags.

The rock, soil, and crop samples were digested with a mixture of $\mathrm{HNO}_{3}$ and $\mathrm{HClO}_{4}$ acids. Se concentration was then determined by using hydride generation atomic fluorescence spectrometry (HG-AFS; AFS9780, Beijing Kechuang Haiguang Instrument Co., Ltd, Beijing, China). For quality control during the chemical analyses, the following Chinese certified reference materials were randomly analyzed with each 


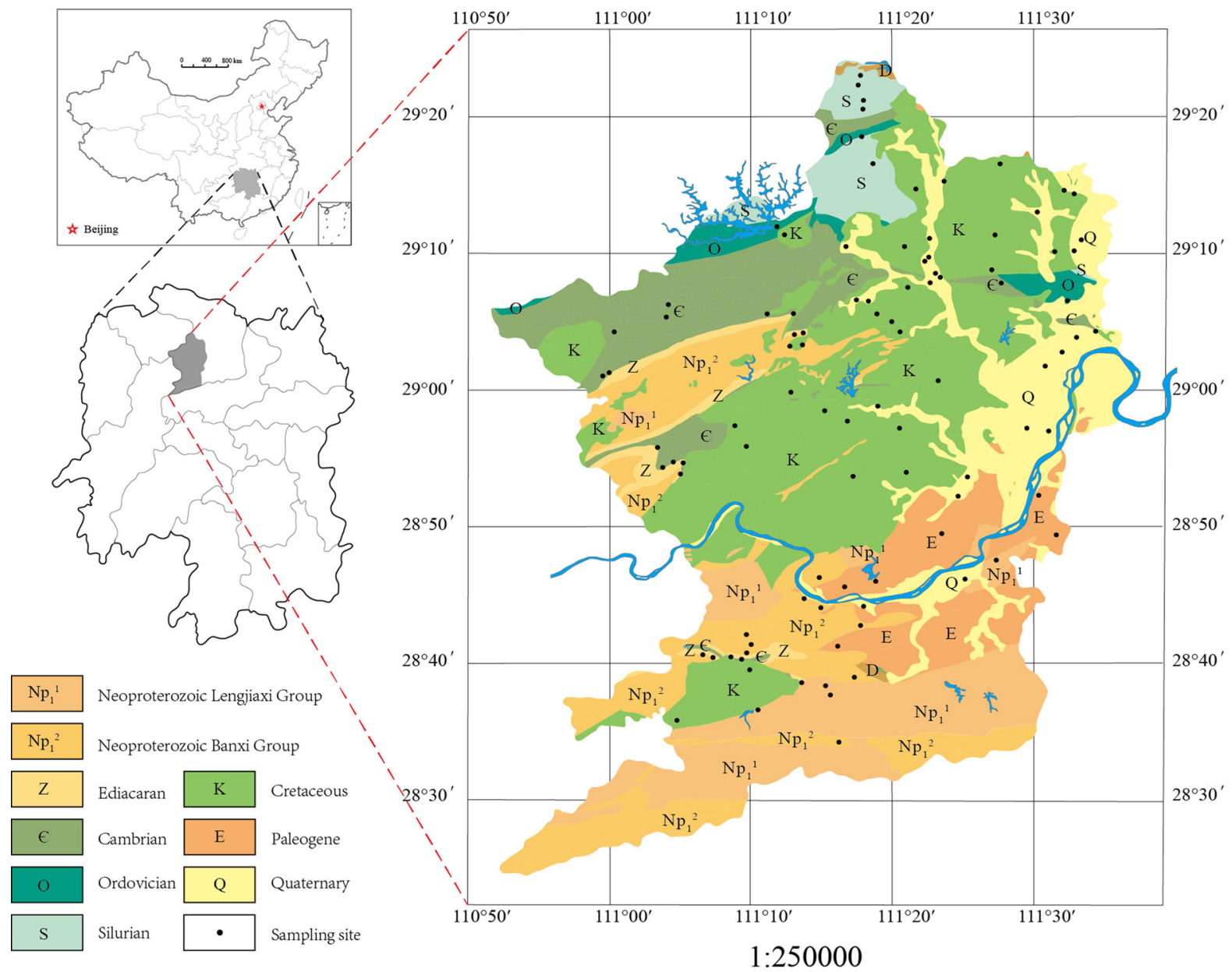

Fig. 1 Geological map of Taoyuan County. Shaded area in the thumbnail (left) shows the location of Taoyuan County in China; black dots in geological map (right) show the sampling sites of this study

batch of rock, soil, and crop samples: soil: GBW07401, GBW07403, and GBW07406; rock: GBW07112; and crop: GBW10010, GBW10014, and GBW10016. In all Se analyses, the relative standard deviation was $<10 \%$.

For extraction of water-soluble $\mathrm{Se}(\mathrm{W}-\mathrm{Se})$ in the rocks and soils, such samples were treated twice with $25 \mathrm{~mL}$ deionized (DI) water and were shaken at $170 \mathrm{rpm}$ for $2 \mathrm{~h}$. After centrifugation, the supernatants were mixed carefully and were digested with a $(5: 1)$ mixed acid of $\mathrm{HNO}_{3}$ and $\mathrm{HClO}_{4} \cdot \mathrm{Se}^{6+}$ was reduced to $\mathrm{Se}^{4+}$ with $6 \mathrm{M} \mathrm{HCl}$, and the Se content in the digestion solution was then measured by using HG-AFS. Details of this method have been published elsewhere (Kulp and Pratt 2004).

\section{Results}

Se in rocks

The Se content in the rocks of Taoyuan County varies greatly, from 0.02 to $223.85 \mathrm{mg} / \mathrm{kg}$, according to the type and age of the rock (Table 1). Lower Cambrian black shales contain the highest $\mathrm{Se}$ content at $21.59 \pm 46.92 \mathrm{mg} / \mathrm{kg}$, followed by Ediacaran black siliceous rocks at $2.91 \pm 1.52 \mathrm{mg} / \mathrm{kg}$ and Middle and Upper Cambrian limestones at $0.68 \pm 0.13 \mathrm{mg} / \mathrm{kg}$. Very little difference, approximately $0.20 \mathrm{mg} / \mathrm{kg}$, was found in the Se content of Ordovician limestones, Proterozoic Lengjiaxi and Banxi group slates, Cretaceous sandstones and mudstones, and Paleocene 
Table 1 Selenium content in bedrock, soil, rice, corn, and beans in Taoyuan County ( $\mathrm{mg} / \mathrm{kg}$ )

\begin{tabular}{|c|c|c|c|c|c|c|c|}
\hline Stratum & Lithology & $\begin{array}{l}\text { Relative } \\
\text { area }(\%)\end{array}$ & Rock & Soil & Rice & Corn & Beans \\
\hline $\begin{array}{l}\text { Neoproterozoic } \\
\text { Lengjiaxi Group }\end{array}$ & Slate & 14 & $\begin{array}{l}0.11-0.28 \\
0.18 \pm 0.06 \\
n=6\end{array}$ & $\begin{array}{l}0.50-1.03 \\
0.71 \pm 0.21 \\
n=4\end{array}$ & & $\begin{array}{l}0.026-0.042 \\
0.034 \pm 0.012 \\
n=2\end{array}$ & \\
\hline $\begin{array}{c}\text { Neoproterozoic } \\
\text { Banxi Group }\end{array}$ & Slate & 16 & $\begin{array}{l}0.08-0.33 \\
0.15 \pm 0.07 \\
n=10\end{array}$ & $\begin{array}{l}0.43-0.67 \\
0.53 \pm 0.09 \\
n=4\end{array}$ & $\begin{array}{l}0.047-0.135 \\
0.097 \pm 0.036 \\
n=6\end{array}$ & $\begin{array}{l}0.032-0.081 \\
0.055 \pm 0.022 \\
n=6\end{array}$ & $\begin{array}{l}0.062-0.157 \\
0.103 \pm 0.041 \\
n=4\end{array}$ \\
\hline Ediacaran & $\begin{array}{l}\text { Black } \\
\quad \text { siliceous } \\
\text { rock }\end{array}$ & 2 & $\begin{array}{l}0.92-6.38 \\
2.91 \pm 1.52 \\
n=24\end{array}$ & $\begin{array}{l}1.41-1.52 \\
1.48 \pm 0.05 \\
n=3\end{array}$ & $\begin{array}{l}0.115 \\
n=1\end{array}$ & $\begin{array}{l}0.051-0.064 \\
0.058 \pm 0.010 \\
n=2\end{array}$ & $\begin{array}{l}0.053-0.234 \\
0.143 \pm 0.128 \\
n=2\end{array}$ \\
\hline Lower Cambrian & Black shale & 2 & $\begin{array}{l}2.13-223.85 \\
21.59 \pm 46.92 \\
n=27\end{array}$ & $\begin{array}{l}0.99-7.05 \\
3.18 \pm 1.95 \\
n=10\end{array}$ & $\begin{array}{l}0.139-4.780 \\
1.040 \pm 1.840 \\
n=6\end{array}$ & $\begin{array}{l}0.215-1.283 \\
0.749 \pm 0.755 \\
n=2\end{array}$ & $\begin{array}{l}0.131-0.334 \\
0.225 \pm 0.102 \\
n=3\end{array}$ \\
\hline $\begin{array}{l}\text { Middle and Upper } \\
\text { Cambrian }\end{array}$ & Limestone & 9 & $\begin{array}{l}0.48-0.87 \\
0.68 \pm 0.13 \\
n=7\end{array}$ & $\begin{array}{l}0.33-0.36 \\
0.34 \pm 0.01 \\
n=2\end{array}$ & $\begin{array}{l}0.06 \\
n=1\end{array}$ & $\begin{array}{l}0.044-0.060 \\
0.052 \pm 0.011 \\
n=2\end{array}$ & $\begin{array}{l}0.108 \\
n=1\end{array}$ \\
\hline Ordovician & Limestone & 2 & $\begin{array}{l}0.23-0.24 \\
0.23 \pm 0.004 \\
n=3\end{array}$ & $\begin{array}{l}0.51-0.65 \\
0.60 \pm 0.06 \\
n=4\end{array}$ & & & \\
\hline Silurian & Siltstone & 4 & $\begin{array}{l}0.02-0.19 \\
0.07 \pm 0.05 \\
n=21\end{array}$ & $\begin{array}{l}0.18-0.72 \\
0.45 \pm 0.17 \\
n=6\end{array}$ & $\begin{array}{l}0.036-0.063 \\
0.050 \pm 0.019 \\
n=2\end{array}$ & & \\
\hline Cretaceous & $\begin{array}{l}\text { Mudstone } \\
\text { Sandstone }\end{array}$ & 34 & $\begin{array}{l}0.09-0.45 \\
0.20 \pm 0.12 \\
n=6\end{array}$ & $\begin{array}{l}0.20-0.68 \\
0.41 \pm 0.12 \\
n=32\end{array}$ & $\begin{array}{l}0.040-0.391 \\
0.093 \pm 0.085 \\
n=17\end{array}$ & $\begin{array}{l}0.038-0.088 \\
0.060 \pm 0.026 \\
n=3\end{array}$ & $\begin{array}{l}0.052-0.245 \\
0.109 \pm 0.050 \\
n=18\end{array}$ \\
\hline Paleocene & Mudstone & 3 & $\begin{array}{l}0.13-0.22 \\
0.18 \pm 0.02 \\
n=11\end{array}$ & $\begin{array}{l}0.35-0.80 \\
0.60 \pm 0.14 \\
n=6\end{array}$ & $\begin{array}{l}0.006-0.098 \\
0.061 \pm 0.036 \\
n=6\end{array}$ & $\begin{array}{l}0.044 \\
n=1\end{array}$ & $\begin{array}{l}0.083-0.135 \\
0.107 \pm 0.026 \\
n=3\end{array}$ \\
\hline Quaternary & $\begin{array}{l}\text { Limnetic } \\
\text { facies } \\
\text { sediment }\end{array}$ & 14 & & $\begin{array}{l}0.31-0.80 \\
0.51 \pm 0.13 \\
n=40\end{array}$ & $\begin{array}{l}0.047-0.151 \\
0.089 \pm 0.030 \\
n=15\end{array}$ & $\begin{array}{l}0.026-0.183 \\
0.077 \pm 0.058 \\
n=6\end{array}$ & $\begin{array}{l}0.065-0.423 \\
0.160 \pm 0.098 \\
n=15\end{array}$ \\
\hline
\end{tabular}

mudstones. The Silurian siltstones contained the lowest concentration of Se at $0.07 \pm 0.05 \mathrm{mg} / \mathrm{kg}$.

Se in soil

The Se contents in the soils of Taoyuan County range from 0.18 to $7.05 \mathrm{mg} / \mathrm{kg}$ (Table 1), with an arithmetic mean value of $0.76 \mathrm{mg} / \mathrm{kg}$. Soil samples with relatively low $(<0.4 \mathrm{mg} / \mathrm{kg})$, moderate $0.4-1.0 \mathrm{mg} / \mathrm{kg}$, and high $(>1.0 \mathrm{mg} / \mathrm{kg})$ Se concentrations account for 6,82 , and $12 \%$ of the total soil samples, respectively.
Because each soil sample represents a different soil area, an arithmetic mean value might mask the actual distribution of soil Se concentration. Therefore, the relative proportion of each geological area sampled in Taoyuan was used as weighting value for calculation of the weighted average for Se soil concentration (0.57 mg/kg).

The mean concentration of Se in the soils of various stratum outcrop areas decreased in the following order: Lower Cambrian $(3.18 \pm 1.95 \mathrm{mg} / \mathrm{kg})>$ Ediacaran $(1.48 \pm 0.05 \mathrm{mg} / \mathrm{kg})>$ Neoproterozoic Lengjiaxi 
group $(0.71 \pm 0.21 \mathrm{mg} / \mathrm{kg})>$ Ordovician $\quad(0.60 \pm$ $0.06 \mathrm{mg} / \mathrm{kg})$, Paleogene $(0.60 \pm 0.14 \mathrm{mg} / \mathrm{kg})>\mathrm{Neo}-$ proterozoic Banxi group $(0.53 \pm 0.09 \mathrm{mg} / \mathrm{kg})>\mathrm{Qu}-$ aternary $\quad(0.51 \pm 0.13 \mathrm{mg} / \mathrm{kg})>$ Silurian $\quad(0.45 \pm$ $0.17 \mathrm{mg} / \mathrm{kg})>$ Cretaceous $\quad(0.41 \pm 0.12 \mathrm{mg} / \mathrm{kg})>$ Middle and Upper Cambrian (0.34 $\pm 0.01 \mathrm{mg} / \mathrm{kg})$.

Se geochemical trends are considered to be influenced by natural processes rather than by county or other political borders. Large counties almost always span several heterogeneous geological provinces; thus, a countywide average for an element may not actually be representative of any specific point in that county. Therefore, a distribution map was selected to more accurately represent the Se concentration in soils across the entire county. In general, interpolation methods are used for the prediction of Se content in unknown areas. However, this method is suitable only for areas with approximately homogeneous geological backgrounds. For areas containing complex geology, predicting Se distribution in soil using Kriging interpolation will likely produce a poor approximation of the actual concentrations (Fig. 2a). Therefore, a predictive soil Se distribution map was created by using the average soil Se values for each of the various geological units (Fig. 2b). As expected, this map (Fig. 2b) provided a better approximation of the actual soil Se geochemical trends.

The highest Se concentrations in Taoyuan County soils occur in the west, where the Lower Cambrian and Ediacaran black rocks series outcrops. These outcrops exhibit banding distributed west to east. Relatively large Se concentrations occur in central and south areas, where Quaternary limnetic sedimentary facies and Neoproterozoic metamorphic volcanic rocks outcrop, respectively. Soils with relatively low Se concentrations are distributed in the central and northern areas, where Middle and Upper Cambrian and Ordovician carbonate rocks and Mesozoic Cretaceous sandstones and conglomerates outcrop.

Water-soluble Se in rocks and soils

The W-Se content in selected rocks and soils is summarized in Table 2. W-Se in rocks from various strata ranged from 1.37 to $1022.55 \mu \mathrm{g} / \mathrm{kg}$. Among all rock samples, Lower Cambrian black shale and Ediacaran black siliceous rock contained the highest amount of W-Se, at 197.81-1022.55 and 101.46-247.86 $\mu \mathrm{g} / \mathrm{kg}$, respectively, whereas that of other rocks was relatively low at $1.37-18.47 \mu \mathrm{g} / \mathrm{kg}$. The W-Se in the Lower Cambrian black shale and Ediacaran black siliceous rock accounted for 2.35-5.19 and 1.83-4.42\% of the total Se, respectively, although that in other rocks showed little difference at $0.90-8.36 \%$, with an average of $3.76 \pm 2.64 \%$. The proportions of $\mathrm{W}-\mathrm{Se}$ in high-Se rocks in Taoyuan, including the Lower Cambrian black shale and Ediacaran black siliceous rock, are similar to those in previous research of Se-enriched strata in South China that showed averages of 5.04 and $7.32 \%$ in black shale and cherts, respectively (Fan et al. 2011).

The W-Se content in soils derived from various strata ranged from 1.60 to $1103.86 \mu \mathrm{g} / \mathrm{kg}$, with a geometric mean of $28.34 \mu \mathrm{g} / \mathrm{kg}$. Soils derived from Lower Cambrian black shale contained the highest amount of W-Se, at 294.45-1103.86 $\mu \mathrm{g} / \mathrm{kg}$. However, the $\mathrm{W}$-Se content in soils derived from Ediacaran black siliceous rocks, at $46.29-70.58 \mu \mathrm{g} / \mathrm{kg}$, was slightly higher than that in other soils, at $1.60-47.68 \mu \mathrm{g} / \mathrm{kg}$ with an average of $22.27 \pm 11.48 \mu \mathrm{g} / \mathrm{kg}$. The W-Se in the soil of Taoyuan was higher than that in soils of the $\mathrm{KBD}$ area; that in the Tibetan Plateau is 5.7-10.9 $\mu \mathrm{g}$ / $\mathrm{kg}$ with an average of $7.6 \mu \mathrm{g} / \mathrm{kg}$ (Wang et al. 2013).

Se in food crops

The Se content in food crops in Taoyuan County ranged from 0.006 to $5.374 \mathrm{mg} / \mathrm{kg}$ (Tables 1,3$)$. The $\mathrm{Se}$ contents in rice, corn, and beans were $0.006-4.780 \mathrm{mg} / \mathrm{kg}$ (mean: $0.190 \pm 0.632 \mathrm{mg} / \mathrm{kg}$ ), $0.026-1.283 \mathrm{mg} / \mathrm{kg}$ (mean: $0.118 \pm 0.253 \mathrm{mg} / \mathrm{kg}$ ), and $0.052-0.413 \mathrm{mg} / \mathrm{kg}$ (mean: $0.133 \pm 0.077 \mathrm{mg} /$ $\mathrm{kg}$ ), respectively (Table 1 ). The $\mathrm{Se}$ in peanuts was $0.010-0.150 \mathrm{mg} / \mathrm{kg}$ (mean: $0.075 \pm 0.035 \mathrm{mg} / \mathrm{kg}$ ), and that for tea was $0.127-0.174 \mathrm{mg} / \mathrm{kg}$ (mean: $0.156 \pm 0.020 \mathrm{mg} / \mathrm{kg}$ ). In other food crops, the Se concentrations ranged from 0.006 to $5.374 \mathrm{mg} / \mathrm{kg}$ (Table 3). Se concentration in the same types of food crops but from different strata outcrop areas varied markedly.

The Se content in food crops grown in the soils of different strata outcrop areas also varied greatly. In general, the rice, corn, and beans grown in the Lower Cambrian black shale outcrop area contained the highest concentrations of Se; that in the rice, corn, and beans from the other strata outcrop areas was relatively low. For other food crops, those grown in Lower Cambrian black shale and Ediacaran black 


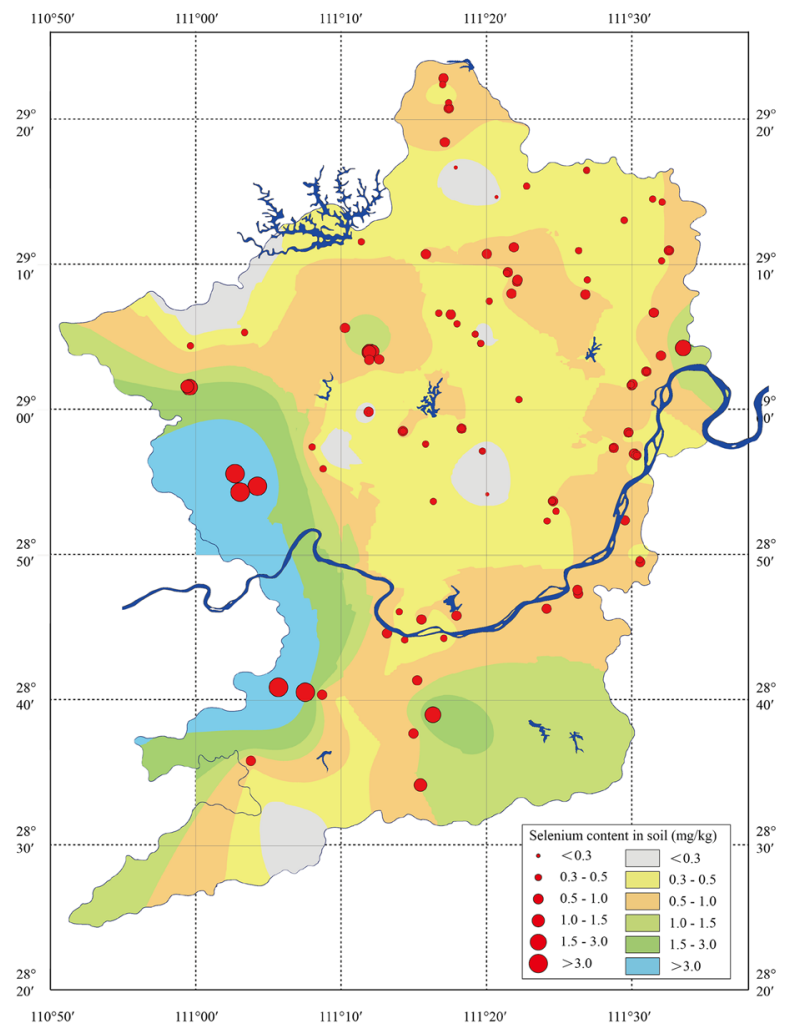

(a)

Fig. 2 Soil Se distribution map of Taoyuan County. Map a (left) was finished by using ArcGIS 10.0 (Kriging interpolation was applied); map b was drawn manually based on the average

siliceous rock outcrop areas also contained significantly high Se (Table 3). For example, the Se contents in the leaves and stalk of asparagus were 3.084 and $5.374 \mathrm{mg} / \mathrm{kg}$, respectively, which is significantly higher than their commonly occurring values of 0.2-0.8 mg/kg (Sirichakwal et al. 2005).

\section{Discussion}

Se levels in Taoyuan County

The weighted mean Se contents $(0.57 \mathrm{mg} / \mathrm{kg})$ of soils from Taoyuan County were 1.43 and 1.97 times higher than the mean soil Se values worldwide $(0.4 \mathrm{mg} / \mathrm{kg})$ and in China $(0.29 \mathrm{mg} / \mathrm{kg}$ ), respectively (Plant et al. 2014). These values are also higher than the mean soil Se values for the USA $(0.26 \mathrm{mg} / \mathrm{kg}$ ) (US Geological Survey 2008), Canada (0.3 mg/kg) (CCME 2009), and Japan (0.51 mg/kg) (Yamada et al. 2009). Se contents

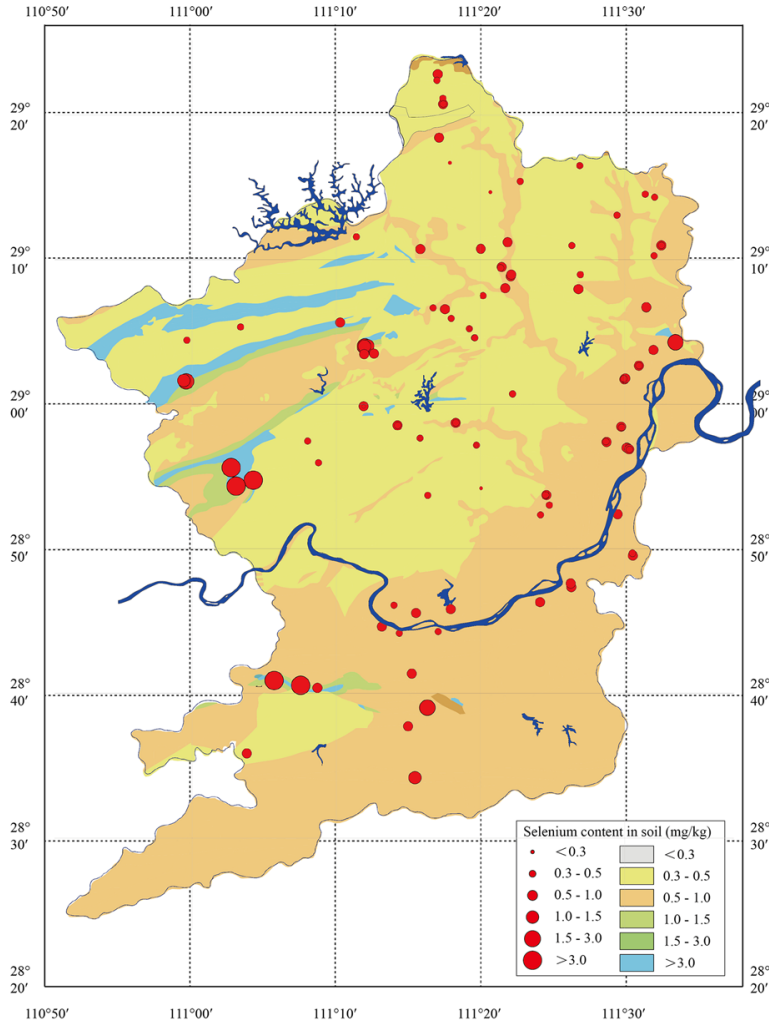

(b)

soil Se values for each of the different geological units. Red dots with different radius refers to soil Se content of this site

in the soils of Taoyuan County were higher than the mean soil Se values in Ziyang County at $0.094-23.530 \mathrm{mg} / \mathrm{kg}$ with a mean of $0.323 \mathrm{mg} / \mathrm{kg}$ (Zhao et al. 1993); however, the values were significantly lower than those in Ziyang County, at $16-36 \mathrm{mg} / \mathrm{kg}$ in Naore village (Luo et al. 2004).

Statistical analysis showed that the Se contents in soils from Se-deficient, Se-moderate, and selenosis areas in China were $0.004-0.48,0.73-5.7$, and 1.49-59 mg/kg, respectively (Plant et al. 2014). Therefore, the soil Se content in Taoyuan County is closest to the moderate Se concentrations, with only a few soil samples containing Se concentrations beyond the moderate range. Furthermore, the arithmetic and weighted mean values of Se concentrations in the soils of Taoyuan County were both higher than the upper limit value for Se-deficient areas in China. The mean values of Se concentration in the main food crops of rice, corn, and beans were also higher than the mean values in moderate Se concentration areas but were 
Table 2 Water-soluble Se content in selected rock and soil samples from different stratum

\begin{tabular}{|c|c|c|c|c|c|c|c|c|c|}
\hline \multirow[t]{2}{*}{ Stratum } & \multicolumn{5}{|l|}{ Rock } & \multicolumn{4}{|l|}{ Soil } \\
\hline & Sample ID & Lithology & $\begin{array}{l}\text { W-Se } \\
(\mu \mathrm{g} / \mathrm{kg})\end{array}$ & $\begin{array}{l}\mathrm{Se}_{\mathrm{tot}} \\
(\mu \mathrm{g} / \mathrm{g})\end{array}$ & $\begin{array}{l}\mathrm{W}-\mathrm{Se} / \\
\mathrm{Se}_{\text {tot }}(\%)\end{array}$ & $\begin{array}{l}\text { Sample } \\
\text { ID }\end{array}$ & $\begin{array}{l}\text { W-Se } \\
(\mu \mathrm{g} / \mathrm{kg})\end{array}$ & $\begin{array}{l}\mathrm{Se}_{\mathrm{tot}} \\
(\mu \mathrm{g} / \mathrm{g})\end{array}$ & $\begin{array}{l}\mathrm{W}-\mathrm{Se} / \\
\mathrm{Se}_{\text {tot }}(\%)\end{array}$ \\
\hline \multirow{2}{*}{$\begin{array}{l}\text { Neoproterozoic } \\
\text { Lengjiaxi Group }\end{array}$} & TY3Y-1 & Slate & 5.55 & 0.16 & 3.42 & TY3T-2 & 30.15 & 1.51 & 1.99 \\
\hline & THYY-1 & Slate & 7.17 & 0.17 & 4.32 & THYT-1 & 9.72 & 0.50 & 1.93 \\
\hline \multirow{2}{*}{$\begin{array}{l}\text { Neoproterozoic } \\
\text { Banxi Group }\end{array}$} & SPY-1 & Slate & 1.87 & 0.21 & 0.90 & SPT-2 & 38.56 & 0.43 & 8.89 \\
\hline & TY-27 & Slate & 5.95 & 0.08 & 7.58 & TT-26 & 1.60 & 0.28 & 0.57 \\
\hline \multirow[t]{2}{*}{ Ediacaran } & JJS-7 & Black siliceous rock & 247.86 & 5.61 & 4.42 & TT-43 & 70.58 & 1.52 & 4.64 \\
\hline & JJS-9 & Black siliceous rock & 101.46 & 5.56 & 1.83 & TT-44 & 46.29 & 1.41 & 3.28 \\
\hline \multirow[t]{2}{*}{ Lower Cambrian } & GYSM-34 & Black shale & 197.81 & 8.43 & 2.35 & GY2T-3 & 1103.86 & 4.26 & 25.94 \\
\hline & TY3Y-6 & Black shale & 1022.55 & 19.72 & 5.19 & TY3T-6 & 294.45 & 6.36 & 4.63 \\
\hline $\begin{array}{l}\text { Middle and Upper } \\
\text { Cambrian }\end{array}$ & TY3Y-8 & Limestone & 4.11 & 0.26 & 1.56 & TY3T-8 & 37.37 & 0.39 & 9.52 \\
\hline \multirow[t]{2}{*}{ Ordovician } & HPY-1 & Limestone & 3.99 & 0.24 & 1.68 & HPT-1 & 18.46 & 0.63 & 2.93 \\
\hline & HSY-1 & Limestone & 18.47 & 0.23 & 8.09 & HST-1 & 29.50 & 0.37 & 7.90 \\
\hline \multirow[t]{2}{*}{ Silurian } & RSY-1 & Siltstone & 4.25 & 0.08 & 5.48 & RST-1 & 21.09 & 0.59 & 3.57 \\
\hline & RSY-22 & Siltstone & 11.79 & 0.14 & 8.36 & RST-5 & 47.68 & 0.72 & 6.60 \\
\hline \multirow[t]{3}{*}{ Cretaceous } & TY-11 & Mudstone & 2.10 & 0.18 & 1.14 & TT-11 & 13.37 & 0.29 & 4.61 \\
\hline & TY-12 & Sandstone & 1.37 & 0.09 & 1.52 & TT-12 & 14.10 & 0.35 & 4.05 \\
\hline & LTY-1 & Mudstone & 3.34 & 0.15 & 2.17 & LTT-4 & 11.65 & 0.45 & 2.60 \\
\hline Paleocene & JSY-11 & Mudstone & 5.83 & 0.22 & 2.67 & JST-1 & 20.31 & 0.57 & 3.53 \\
\hline \multirow[t]{2}{*}{ Quaternary } & & & & & & QH2T-1 & 20.44 & 0.63 & 3.27 \\
\hline & & & & & & $\mathrm{QH} 2 \mathrm{~T}-2$ & 30.31 & 0.80 & 3.78 \\
\hline
\end{tabular}

$S e_{t o t}$ total Se in rock or soil samples, $W$-Se water-soluble Se

lower than those in selenosis areas (Yang et al. 1983; Fordyce 2013). The Se concentration in Taoyuan County teas was lower than that in regulated Seenriched teas $(0.25-4.00 \mathrm{mg} / \mathrm{kg}, \mathrm{NY} / \mathrm{T} 600-2002)$ and in teas $(0.6 \pm 0.6 \mathrm{mg} / \mathrm{kg})$ from Ziyang County (Cheng et al. 1991).

Therefore, the Se levels in the environmental materials of Taoyuan County can be categorized as moderate according to the Chinese scale, which is in contrast to previous determinations of Se deficiency in the area.

\section{Source of Se in Taoyuan County}

The Se concentrations in the soil and food crops varied greatly, in which the highest value was hundreds of times greater than the lowest value. Furthermore, soils and food crops contain high Se values when the bedrock also contains high Se values (Fig. 3). An exponential relationship was found between the average Se contents in bedrock and those in soil and food crops (Fig. 4). This indicates that the Se content of the bedrock controls the Se concentrations in soils and food crops.

Naore Village, Ziyang County, Shannxi Province, is a selenosis area of China. In this area, Luo et al. (2004) performed a detailed study of the Se content, distribution pattern, and sources of Se. The soil was found to be derived from high-Se, pyritic, black carbonaceous slate and volcanic tuff of the Lujiaping Formation, which is early Cambrian and late Neoproterozoic in age and is exposed in this area. The authors deduced that this series of Se-enriched rocks also occurs in other parts of the Daba region of South Qinling Mountain. In addition, Se-enriched black carbonaceous shales of early Cambrian age occur in several other provinces of South China. The Lower Cambrian and Ediacaran black rock series is widely distributed in the Niuchehe, Zhongjiapu, Ligonggang, and Guanyinsi villages of Taoyuan County, and the strata age and rock type are the same as those in Naore Village. Soil and crop samples containing high Se 
Table 3 Selenium content in vegetables and teas in Taoyuan County (mg/kg)

\begin{tabular}{|c|c|c|c|}
\hline Crops & Stratum & Bedrock & Se content \\
\hline \multirow[t]{5}{*}{ Peanut } & Lower Cambrian & Black shale & $0.150(n=1)$ \\
\hline & Middle and Upper Cambrian & Limestone & $0.048(n=1)$ \\
\hline & Cretaceous & Mudstone and sandstone & $0.069 \pm 0.015(n=6)$ \\
\hline & Paleocene & Mudstone & $0.066(n=1)$ \\
\hline & Quaternary & Limnetic facies sediment & $0.075 \pm 0.046(n=4)$ \\
\hline \multirow[t]{2}{*}{ Garlic } & Neoproterozoic Banxi Group & Slate & $0.435(n=1)$ \\
\hline & Cretaceous & Mudstone and sandstone & $0.102(n=1)$ \\
\hline \multirow[t]{2}{*}{ Garlic sprout } & Neoproterozoic Banxi Group & Slate & $0.197(n=1)$ \\
\hline & Cretaceous & Mudstone and sandstone & $0.060(n=1)$ \\
\hline \multirow[t]{5}{*}{ Chili } & Neoproterozoic Lenjiaxi Group & Slate & $0.143(n=1)$ \\
\hline & Ediacaran & Black siliceous rock & $0.605(n=1)$ \\
\hline & Middle and Upper Cambrian & Limestone & $0.035(n=1)$ \\
\hline & Cretaceous & Mudstone and sandstone & $0.045(n=1)$ \\
\hline & Quaternary & Limnetic facies sediment & $0.088(n=1)$ \\
\hline Pumpkin & Neoproterozoic Banxi Group & Slate & $0.046(n=1)$ \\
\hline Asparagus leaves & Lower Cambrian & Black shale & $5.374(n=1)$ \\
\hline Asparagus stalk & Lower Cambrian & Black shale & $3.084(n=1)$ \\
\hline Apium & Neoproterozoic Lenjiaxi Group & Slate & $0.125(n=1)$ \\
\hline Houttuynia & Neoproterozoic Lenjiaxi Group & Slate & $0.071(n=1)$ \\
\hline Fiddlehead & Neoproterozoic Lenjiaxi Group & Slate & $0.179(n=1)$ \\
\hline \multirow[t]{2}{*}{ Sweet potato } & Neoproterozoic Banxi Group & Slate & $0.049 \pm 0.014(n=2)$ \\
\hline & Middle and Upper Cambrian & Limestone & $0.044(n=1)$ \\
\hline Camellia seed & Quaternary & Limnetic facies sediment & $0.013(n=1)$ \\
\hline \multirow[t]{2}{*}{ Tea } & Neoproterozoic Lengjiaxi Group & Slate & $0.174(n=1)$ \\
\hline & Cretaceous & Mudstone and sandstone & $0.147 \pm 0.019(n=2)$ \\
\hline
\end{tabular}

concentrations were collected from all of the aforementioned villages. On this basis, it can be concluded that the Se-enriched Lower Cambrian and Ediacaran black rocks series is the source of the seleniferous soils in Taoyuan County.

Effect of Se in rocks on soil and crop Se distribution

In general, Se in rock is relatively low, with $0.05 \mathrm{mg} /$ $\mathrm{kg}$ measured in the Earth's crust. As given in Table 1, the Se content in slate, limestone, siltstone mudstone, and sandstone is $0.02-0.87 \mathrm{mg} / \mathrm{kg}$. Very high Se concentrations were found in some black rock series including black shale and cherts (Feng et al. 2010). Similarly, the Se contents in Lower Cambrian black shale and Ediacaran black siliceous rocks were significantly higher than those in the other rocks of
Taoyuan County. Se in rock is the most important natural source of Se in the environment. High-Se rocks such as the Lower Cambrian-Ediacaran black rock series act as sinks for the seleniferous environment, whereas low-Se rocks exposed in the middle and north regions of Taoyuan County are likely responsible for the development of the low-Se environment.

Se concentrations in soils derived from the Lower Cambrian-Ediacaran black rock series were significantly lower than those in their origin materials (Tables 1, 2). However, soils derived from the other strata contained higher Se than their origin materials (Tables 1, 2). This result indicates that other factors affect Se distribution in soil. Johnson et al. (2000) suggested that organic-rich soils may have higher Se in Zhangjiakou District and the seleniferous soils are related to organic matter and volcanic materials in Japan (Yamada et al. 2009). Additional, Se(IV) is 


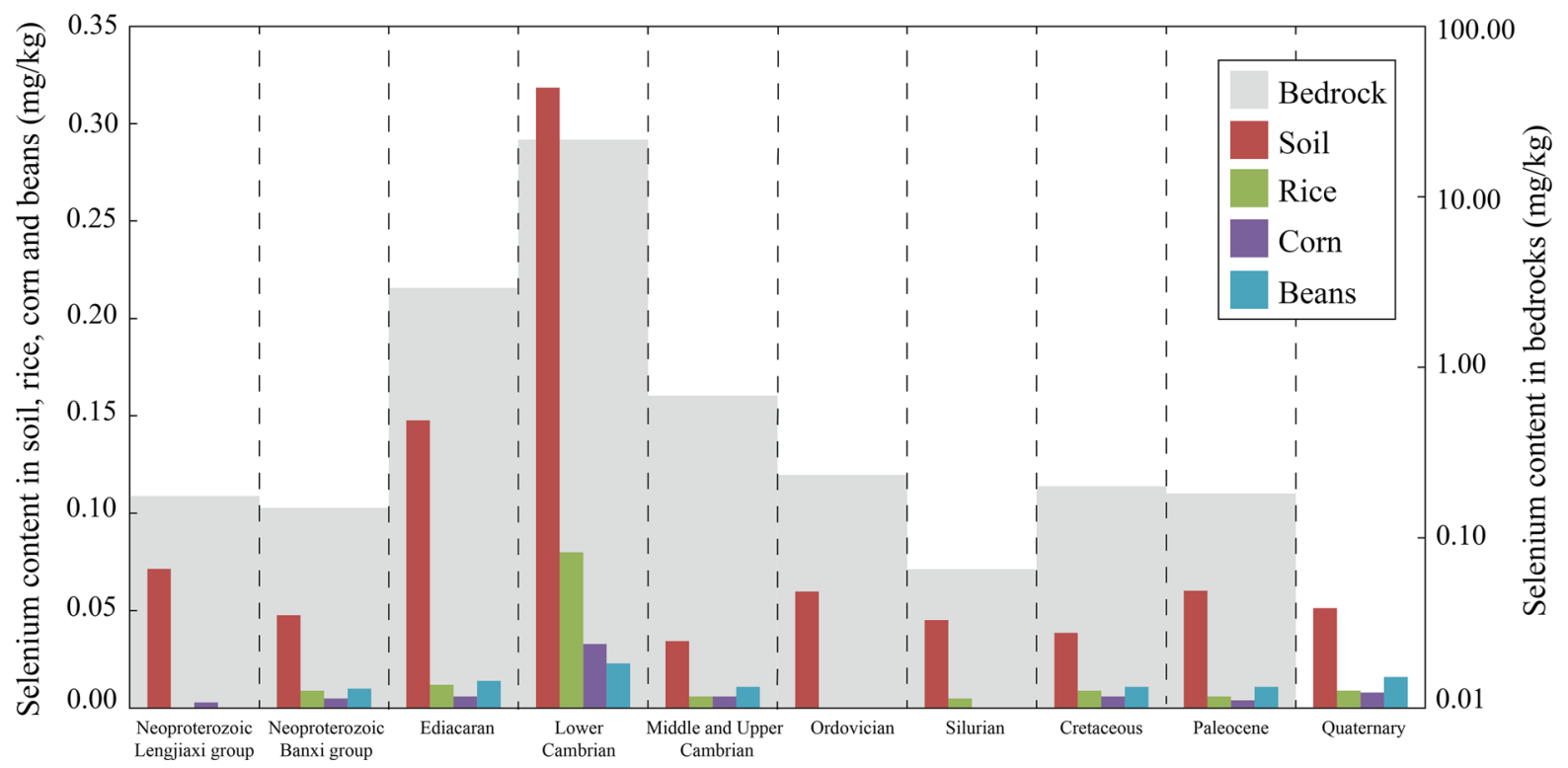

Fig. 3 Effects of selenium content in bedrocks on selenium content in soil and food crops
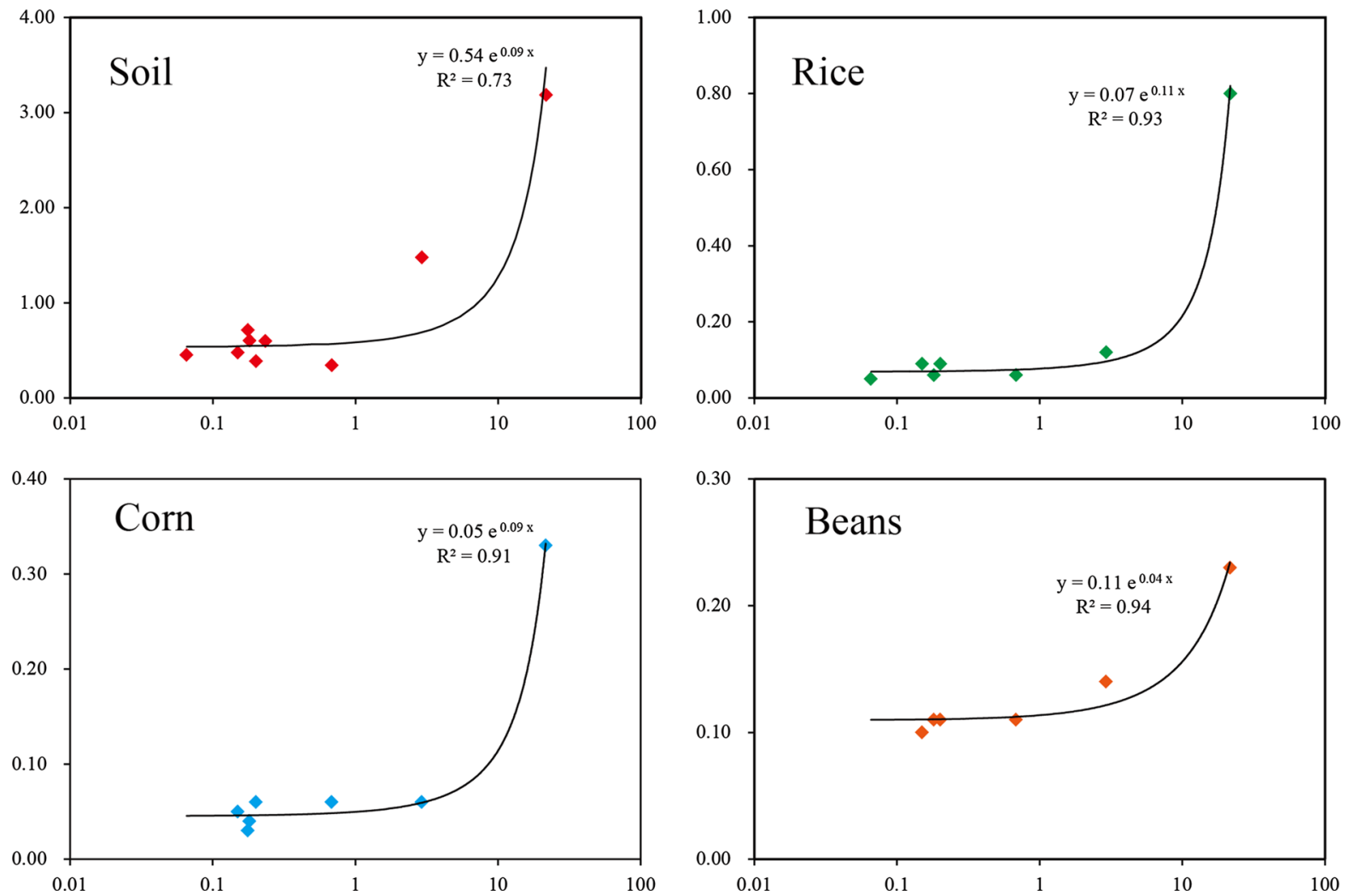

Fig. 4 Relationship between selenium content in bedrocks and in soil and food crops 
strongly absorbed in iron oxides in acidic soils (Plant et al. 2014). These findings suggest that factors other than Se in rock are responsible for the relatively lowSe environment in Taoyuan County.

Bioavailable Se plays a more important role than total Se in soil in Se uptake by plants. W-Se is the major form of bioavailable Se. As given in Tables 1 and 2, W-Se in the Lower Cambrian-Ediacaran black rocks series and their derived soils is significantly higher than that in the other rocks and soils, respectively. This indicates that the high-Se Lower Cambrian-Ediacaran black rocks series can provide significantly more $\mathrm{W}-\mathrm{Se}$ than the other rocks. Therefore, food crops planted on the Lower CambrianEdiacaran black rocks series outcrop areas have more available W-Se. The accumulation of heavy metals in the environment to toxic concentrations may lead to ecological damage (Ashraf et al. 2011a, b; Abu Bakar et al. 2013). Excessive amounts of $\mathrm{W}-\mathrm{Se}$ in the soil lead to toxic amounts of Se in edible parts of food crops, which can lead to Se poisoning in animals and human. Therefore, the Lower Cambrian-Ediacaran black rocks series outcrop areas are potential areas of Se poisoning.

\section{Conclusions}

This study has determined that the Se contents in bedrock, soil, and food crops in Taoyuan County, China, vary greatly at $0.02-223.85,0.18-7.05$, and 0.006-5.374 mg/kg, respectively. The Se distribution in Taoyuan County is extremely variable, with the highest Se concentrations occurring in Lower Cambrian and Ediacaran strata outcrop areas. Relatively high Se concentrations occur in Quaternary, Neoproterozoic strata outcrop areas, whereas relatively low Se concentrations occur in Middle and Upper Cambrian, Ordovician, and Mesozoic strata outcrop areas. The Se content in bedrock is the main controlling factor for the Se concentrations in soil and food crops. The seleniferous environment in Taoyuan County shows a banding west-east distribution. Its source is the Se-enriched Lower Cambrian-Ediacaran black rocks series, which is widespread in the Yangtze Platform in South China. The Se contents in these rocks, including the Lower Cambrian Niutitang Formation black shale and Ediacaran Liuchapo Formation cherts, are significantly higher than those in other rocks. Therefore, we conclude that potential environments of $\mathrm{Se}$ poisoning are distributed in areas in which the Lower CambrianEdiacaran black rock series outcrops. Thus, caution should be heeded if these areas are cultivated.

Acknowledgments This research was supported by the National Key Basic Research Program of China (973 Program; Grant No. 2014CB238906), the National Natural Science Foundation of China (Grant Nos. 41172310 and 41472322), and the parochial program of the "Selenium resources survey in Taoyuan County." Many heartfelt thanks are given to the staff members of the Government of Taoyuan County for their strong support and active cooperation. The authors also express heartfelt thanks to Yan Songgui, Zhong Jitai, Liu Maoqiu, and Peng Jingchun for their assistance in collecting the samples.

\section{References}

Abu Bakar, A. F., Yusoff, I., Fatt, N. T., Othman, F., \& Ashraf, M. A. (2013). Arsenic, zinc, and aluminium removal from gold mine wastewater effluents and accumulation by submerged aquatic plants (Cabomba piauhyensis, Egeria densa, and Hydrilla verticillata). BioMed Research International, 2013, 1-7.

Ashraf, M. A., Maah, M., \& Yusoff, I. (2011a). Assessment of heavy metals in the fish samples of mined out ponds Bestari Jaya, Peninsular Malaysia. Proceedings of the Indian National Science Academy, 77(1), 57-67.

Ashraf, M. A., Maah, M., \& Yusoff, I. (2011b). Bioaccumulation of heavy metals in fish species collected from former tin mining catchment. International Journal of Environmental Research, 6(1), 209-218.

CCME. (2009). Canadian soil quality guidelines: selenium environmental and human health effects. Scientific Supporting Document. Winnipeg: Canadian Council of Ministers of the Environment.

Cheng, L., Mei, Z., \& Huang, L. (1991). Investigation on the selenium content in Ziyang tea. Journal of Tea Science, 11(1), 63-66.

Combs, G. F. (2001). Selenium in global food systems. British Journal of Nutrition, 85(05), 517-547.

Duntas, L. H., \& Benvenga, S. (2014). Selenium: an element for life. Endocrine, 48(3), 756-775.

Fan, H., Wen, H., Hu, R., \& Zhao, H. (2011). Selenium speciation in lower Cambrian Se-enriched strata in South China and its geological implications. Geochimica et Cosmochimica Acta, 75(23), 7725-7740.

FAO, \& WHO. (2001). Human vitamin and mineral requirements. Report of a joint FAO/WHO expert consultation. Bangkok, Thailand: Food and Nutrition Division, FAO.

Feng, C., Liu, S., Hu, R., Liu, J., Luo, T., Chi, G., et al. (2010). Geochemistry of Lower Cambrian Se-rich black rock series in Zunyi, Guizhou Province, Southwest China: The petrogenesis and enrichment mechanism of selenium (in Chinese). Earth Science-Journal of China University of Geosciences, 35(6), 947-958. 
Fordyce, F. M. (2013). Selenium deficiency and toxicity in the environment. In O. Selinus (Ed.), Essentials of medical geology (revised edition). Berlin: Springer.

Fordyce, F. M., Guangdi, Z., Green, K., \& Xinping, L. (2000). Soil, grain and water chemistry in relation to human selenium-responsive diseases in Enshi District, China. Applied Geochemistry, 15(1), 117-132.

Ge, D., Huang, Y., Yang, Z., \& Luo, C. (1996). Selenium distribution in paddy soil Hunan province, China. Hunan Agricultural Sciences, 6, 25-26.

Johnson, C., Ge, X., Green, K., \& Liu, X. (2000). Selenium distribution in the local environment of selected villages of the Keshan Disease belt, Zhangjiakou District, Hebei Province, People's Republic of China. Applied Geochemistry, 15(3), 385-401.

Kubota, J., Allaway, W. H., Carter, D. L., Gary, E. E., \& Lazar, V. A. (1967). Selenium in crops in the United States in relation to selenium-responsive diseases of animals. Journal of Agricultural and Food Chemistry, 15(3), 448-453.

Kulp, T. R., \& Pratt, L. M. (2004). Speciation and weathering of selenium in Upper Cretaceous chalk and shale from South Dakota and Wyoming, USA. Geochimica et Cosmochimica Acta, 68(18), 3687-3701.

Liu, J., Lu, Z., \& Su, Q. (1985). Regional selenium deficiency of feedstuffs in China. Scientia Agricultura Sinica, 4, 76-79.

Luo, K., Xu, L., Tan, J. A., Wang, D., \& Xiang, L. (2004). Selenium source in the selenosis area of the Daba region, South Qinling Mountain, China. Environmental Geology, 45(3), 426-432.

Moxon, A. L. (1937). Alkali disease or selenium poisoning. South Dakota State Colloge Bulletin, 311, 99.

Plant, J. A., Bone, J., Voulvoulis, N., Kinniburgh, D. G., Smedley, P. L., Fordyce, F. M., et al. (2014). 11.2-arsenic and selenium. In H. D. H. K. Turekian (Ed.), Treatise on geochemistry (second edition) (pp. 13-57). Oxford: Elsevier.
Rawlins, B. G., McGrath, S. P., Scheib, A. J., Breward, N., Cave, M., Lister, T. R., et al. (2012). The advanced soil geochemical atlas of England and Wales. Keyworth: British Geological Survey.

Sirichakwal, P. P., Puwastien, P., Polngam, J., \& Kongkachuichai, R. (2005). Selenium content of Thai foods. Journal of Food Composition and Analysis, 18(1), 47-59.

Tan, J. A. (1989). The atlas of endemic diseases and their environments in the People's Republic of China. Beijing: Science Press.

Tan, J. A., Zhu, W., Wang, W., Li, R., Hou, S., Wang, D., et al. (2002). Selenium in soil and endemic diseases in China. Science of the Total Environment, 284(1), 227-235.

US Geological Survey. (2008). Selenium in Counties of the Conterminous States. http://mrdata.usgs.gov/geochem/ doc/averages/se/usa.html.

Wang, J., Li, H., Li, Y., Yu, J., Yang, L., Feng, F., et al. (2013). Speciation, distribution, and bioavailability of soil selenium in the Tibetan Plateau Kashin-Beck Disease Area: A Case Study in Songpan County, Sichuan Province. Biological Trace Element Research, 156(1-3), 367-375.

Yamada, H., Kamada, A., Usuki, M., \& Yanai, J. (2009). Total selenium content of agricultural soils in Japan. Soil Science and Plant Nutrition, 55(5), 616-622.

Yang, G. Q., Wang, S. Z., Zhou, R. H., \& Sun, S. Z. (1983). Endemic selenium intoxication of humans in China. The American Journal of Clinical Nutrition, 37(5), 872-881.

Yuan, L., Zhu, Y., Lin, Z.-Q., Banuelos, G., Li, W., \& Yin, X. (2013). A novel selenocystine-accumulating plant in selenium-mine drainage area in Enshi, China. PLoS ONE, 8(6), e65615.

Zhao, C., Ren, J., \& Xue, C. (1993). Selenium in soils of selenium-rich areas in Ziyang county. Acta Pedologica Sinica, 30(3), 253-259. 